\title{
A RAPID FLUOROMETRIC METHOD FOR THE DETERMINATION OF DNA IN HUMAN SEMEN
}

\author{
R. N. PETERSON, K. SILVERSTEIN AND M. FREUND \\ Laboratory of Reproductive Pharmacology, Department of Pharmacology, \\ New York Medical College, Valhalla, New York 10595, U.S.A.
}

(Received 3rd June 1974)

The dye, ethidium bromide, markedly increases its fluorescence quantum efficiency when bound to double-stranded undenatured nucleic acid (Le Pecq, Yat \& Paoletti, 1964; Le Pecq \& Paoletti, 1966). When added to sperm suspensions, ethidium bromide binds almost exclusively to the sperm head and induces an intense fluorescence (Edelman \& Millette, 1971).

In this report, a method for DNA assay in human semen and washed sperm suspensions is described. The method takes advantage of these earlier findings and permits quantitative estimates of DNA and, indirectly, of sperm counts to be made in less than 15 min.

Semen specimens were obtained from medical students. Sperm counts were made in quadruplicate using a haemocytometer, as described by Freund \& Carol (1964). The procedure for preparing washed sperm suspensions and the composition of the buffered salt solutions used to suspend spermatozoa have been described elsewhere (Peterson \& Freund, 1969). Glycine was used in the place of tris(hydroxymethyl)aminomethane to buffer solutions at $\mathrm{pH} 9.7$ and EDTA $\left(10^{-3} \mathrm{M}\right)$ was added to all solutions. Assays were carried out in a Turner model 111 fluorometer. Excitatory light at $360 \mathrm{~nm}$ was provided by the 7-60 narrow pass filter; emission of $590 \mathrm{~nm}$ was measured using a number 22 sharp cut-off filter which passes light at wavelengths greater than $560 \mathrm{~nm}$. The sample compartment was thermostatically maintained at $21^{\circ} \mathrm{C}$. Assay tubes were filled with $4 \mathrm{ml}$ buffer containing ethidium bromide at a concentration of $5 \mu \mathrm{g} / \mathrm{ml}$. The fluorometer was adjusted to read zero fluorescence before the addition of sample. Samples were added in duplicate by micropipette ( 1 to $50 \mu \mathrm{l}$, depending on the sperm concentration), and the fluorescence was measured at time intervals dictated by the purpose of a particular experiment. When semen was assayed, it was necessary to correct the total fluorescence of the sample for the small amount of fluorescence contributed by the seminal plasma. This was done by centrifuging a small portion of the specimen (at 20,000 $\mathrm{g}$ for $5 \mathrm{~min}$ ) and determining the fluorescence of an appropriate aliquot of the resulting cell-free supernatant. In some experiments, the DNA content of the semen was determined by modification of the diphenylamine method described by Giles \& Myers (1965). In these assays, aliquots of semen (up to $1.8 \mathrm{ml}$ ) were mixed with perchloric acid $(0.25 \mathrm{~N}$ final concentration) and chilled for $30 \mathrm{~min}$. The samples were centrifuged at $20,000 \mathrm{~g}$ for $20 \mathrm{~min}$ and the supernatant was discarded. Pellets were dispersed in $0.5 \mathrm{ml}$ perchloric acid and diluted to a final volume of 
$4 \mathrm{ml}$ with the acid. These samples were heated for $15 \mathrm{~min}$ at $70^{\circ} \mathrm{C}$, cooled, and centrifuged at $20,000 \mathrm{~g}$ for $20 \mathrm{~min}$. Aliquots of the supernatant $(2 \mathrm{ml})$ were mixed with $2 \mathrm{ml}$ of $4 \%$ diphenylamine and $0.1 \mathrm{ml}$ acetaldehyde $(1.6 \mathrm{mg} / \mathrm{ml})$ and incubated overnight at $30^{\circ} \mathrm{G}$. The optical densities of samples and standards were measured at $595 \mathrm{~nm}$ and $700 \mathrm{~nm}$ in a Bausch and Lomb Spectronic 100 spectrophotometer.

Highly purified calf thymus DNA, obtained from the Boehringer-Mannheim Company, was used as standard in all assays. Ethidium bromide (2,7-diamino9-phenylphenanthridine-10-ethyl bromide) was purchased from Cal Biochem. Other chemicals were purchased from the Sigma Chemical Company.

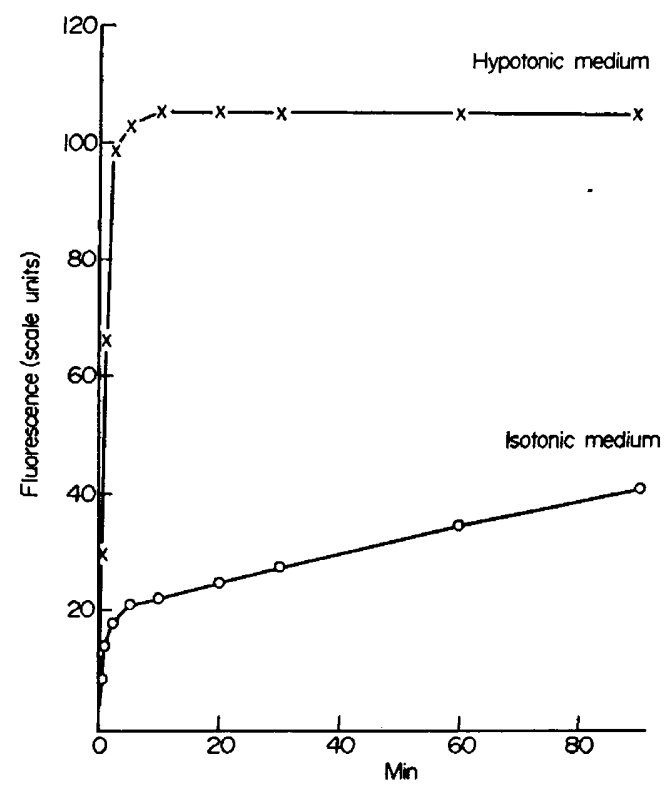

TEXT-FIG. 1. A comparison of the fluorescence of hypotonic and isotonic suspensions of semen containing ethidium bromide. A $25-\mu \mathrm{l}$ aliquot of pooled semen $\left(0.65 \times 10^{8}\right.$ spermatozoa $/ \mathrm{ml}$ ) was added to $4 \mathrm{ml}$ buffer solution containing ethidium bromide $(5 \mu \mathrm{g} / \mathrm{ml})$ and either $0.02 \mathrm{M}$-glycine, $\mathrm{pH} 9.7(\times)$, or a standard isotonic salt solution containing 0.02 M-glycine, $\mathrm{pH} 9 \cdot 7(0)$.

In initial experiments, semen or washed sperm suspensions were mixed with standard salt solutions containing ethidium bromide and the fluorescence changes were determined. Although an increase in the fluorescence of the dye, proportional to cell concentration, was obtained, the fluorescence of the solutions increased slowly with time which reduced the reproducibility of assay. Since the fluorescence of solutions containing ethidium bromide and calf thymus DNA reached a constant value within seconds of mixing, it was apparent that the increase in fluorescence as a function of time with spermatozoa was due to the slow penetration of the dye into the chromatin-containing space of the cell. Estimates of the DNA content of human spermatozoa by the diphenylamine method indicated that about 10 to $20 \%$ of the total cellular DNA was accessible to the dye immediately after mixing in isotonic solutions. Since dye penetration was more rapid at alkaline $\mathrm{pH}$ and since Le Pecq \& Paoletti (1966) 
reported that dye protein interactions were minimized in alkaline solution, further experiments were carried out at $\mathrm{pH} 9.7$ in solutions of various ionic strengths. Text-figure 1 shows that when semen was diluted with a hypotonic solution (0.02 $\mathrm{M}$-glycine at $\mathrm{pH} \mathrm{9.7)}$, there was an initial rapid rise in fluorescence which reached a peak in about $10 \mathrm{~min}$ and then remained constant. The peak fluorescence was about four times the value obtained when the same quantity of semen was mixed with an isotonic solution at the same $\mathrm{pH}$. Considering the total number of cells added to the hypotonic medium and the comparative fluorescence of standard DNA solutions, it was apparent that virtually all the

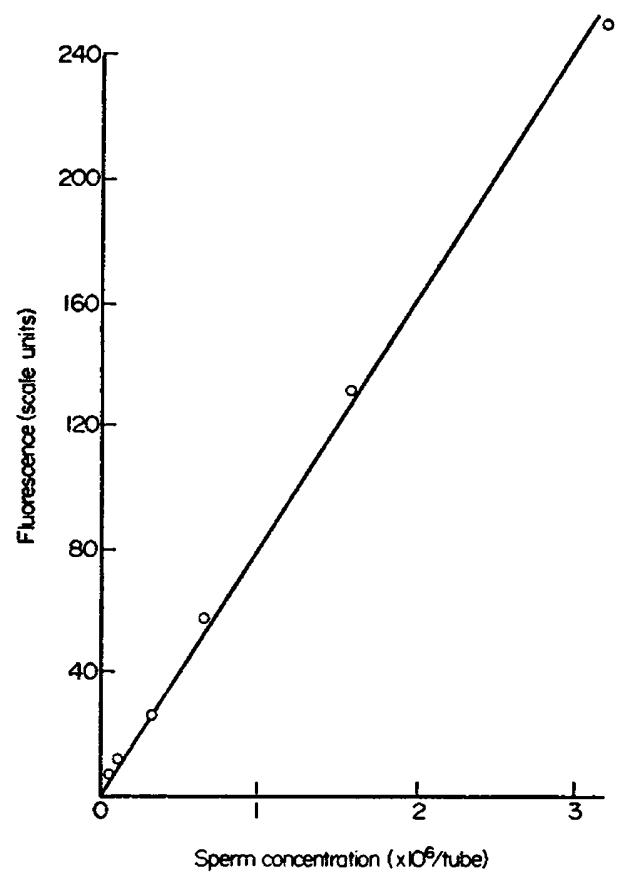

TEXr-FIG. 2. The fluorescence of increasing concentrations of washed spermatozoa diluted in hypotonic glycine buffer containing ethidium bromide. Aliquots ( 1 to $50 \mu \mathrm{l}$ ) of a washed sperm suspension $\left(0.64 \times 10^{8}\right.$ spermatozoa $\left./ \mathrm{ml}\right)$ were added to tubes containing $0.02 \mathrm{M}-$ glycine buffer $\mathrm{pH}$ 9.7. Measurements of fluorescence were made 15 min after mixing. The ordinate is given as instrument scale units. One unit is equivalent to the fluorescence produced by $0.0147 \mu \mathrm{g}$ of a standard solution of calf thymus DNA.

cellular DNA was made accessible to the dye in the hypotonic medium. This is shown directly by the results of experiments in which spermatozoa were washed free of seminal plasma, resuspended in an isotonic salts medium at $\mathrm{pH} 7.4$ and then diluted as indicated in the hypotonic medium containing ethidium bromide for fluorescence assay. The increase in fluorescence (Text-fig. 2) was linear with cell count over the 50 -fold range examined and the value for total DNA per cell $(2.74 \mu \mathrm{g})$, obtained from the slope of the curve, agreed with that $(2.47 \mu \mathrm{g})$ obtained by the diphenylamine method and with a value of 2.46 that was reported by Leuchtenberger, Leuchtenberger, Schrader \& Neu (1956).

In separate experiments, twenty-one specimens of semen were assayed for sperm concentration and DNA using the ethidium bromide method. Sperm 
concentration in these specimens ranged from $10 \times 10^{6} / \mathrm{ml}$ to $176 \times 10^{6} / \mathrm{ml}$. Various amounts of the specimens $(5,10$ or $25 \mu$ l depending on the sperm concentration) were added directly to $4 \mathrm{ml}$ of the dye-buffer solution and the fluorescence of the solutions was measured after $15 \mathrm{~min}$. Corrections were made in all assays for the small amount of fluorescence contributed by the seminal plasma. The average value of DNA/sperm cell obtained by this method $(2.43 \mu \mathrm{g} \pm 0.13)$ was almost identical to that obtained by the diphenylamine method. Both the diphenylamine and ethidium bromide assays showed a similar variation in the average DNA/cell which was probably due, in part, to the lack of reproducibility of the haemocytometer counting technique, which has been shown to be no better than $\pm 20 \%$ (Freund \& Carol, 1964). The inhomogeneity of sperm populations in semen as shown by morphological abnormalities, especially of the sperm head (Freund, 1966) may also contribute to some of the variation in DNA content per spermatozoon noted in different specimens.

The ethidium bromide assay provides a rapid method for determining the sperm count in specimens where the sperm concentration ranges between 10 and $200 \times 10^{6}$ cells $/ \mathrm{ml}$, i.e. more than $90 \%$ of specimens encountered in this laboratory. When the sperm cell count falls below $5 \times 10^{6} / \mathrm{ml}$, the accuracy of the method can be expected to decline since the fluorescence of the seminal plasma will contribute a more significant portion of the total fluorescence of the sample. Even in these circumstances, however, the method may be useful to screen azoospermic or oligospermic specimens since the fluorescence of spermfree specimens rapidly reaches equilibrium $(<1 \mathrm{~min})$ while specimens that contain as few as 500,000 cells $/ \mathrm{ml}$ show a characteristic increase in fluorescence for at least $10 \mathrm{~min}$ before the level becomes constant.

We wish to acknowledge the fact that the concept of a chemical detection method for spermatozoa was given to us by Mr Louis Bucalo of Investors in Ventures, Inc.

\section{REFERENCES}

Edelman, G. M. \& Milette, G. F. (1971) Molecular probes of spermatozoan structures. Proc. natn. Acad. Sci. U.S.A. 68, 2436.

FReUNd, M. (1966) Standards for the rating of human sperm morphology. A cooperative study. Int. $\mathcal{J}$. Fert. 11, 97.

FreUnd, M. \& Garol, B. (1964) Factors affecting haemocytometer counts of sperm concentration in human semen. F. Reprod. Fert. 8, 149.

Giles, K. W. \& MYrRs, A. (1965) An improved diphenylamine method for the estimation of deoxyribonucleic acid. Nature, Lond. 93, 206.

Le PecQ, J.-B., YAt, P. \& Paoletti, C. (1964) Interaction du bromhydrade d'ethidium avec les acides nucléiques. Etude spectrofluorimetrique. C. r. hebd. Seanc. Acad. Sci., Paris, 259, 786.

Le Pece, J.-B. \& PAoletri, G. (1966) A new fluorometric method for RNA and DNA determination. Analyt. Biochem. 17, 100.

LeUchtenberger, G., LeUchtenberger, R., SchradrR, F. \& NeU, D. R. (1956) Reduced amounts of desoxyribose nucleic acid in testicular germ cells of infertile men with active spermatogenesis. Lab. Invest. 5, 422.

Peterson, R. N. \& Freund, M. (1969) Glycolysis by washed suspensions of human spermatozoa. Effect of substrate concentration and changes in medium composition on the rate of glycolysis. Biol. Reprod. 1, 238. 